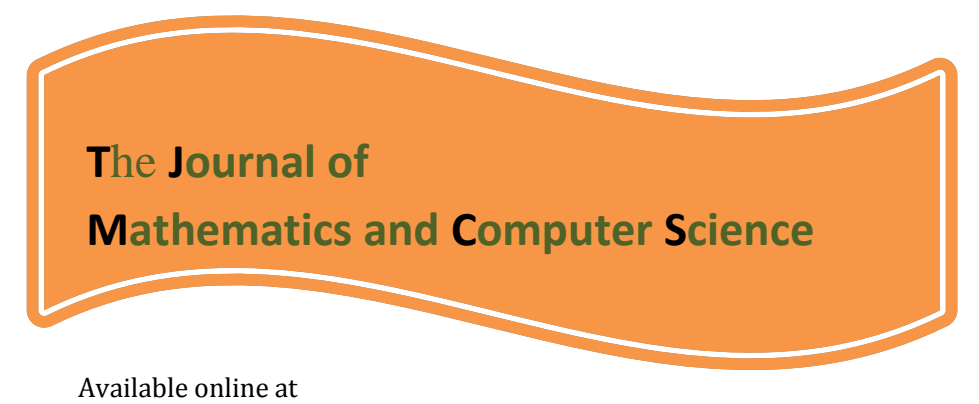

http://www.TIMCS.com

The Journal of Mathematics and Computer Science Vol .3 No.1 (2011) 53-70

\title{
Impact of International Market Entry Strategy on Export Performance ${ }^{1}$
}

\author{
Jamshid Salehi Sadaghiania, Nabi Allah Dehghanb, Kambiz Navabi Zandc \\ aProfessor of industrial management of Faculty of Management, \\ Allame Taba Tabaee University, Iran \\ bAssistant Professor of business management of Faculty of Management, \\ Shahid Sattari University, Iran \\ cMaster of Business Administration, Payamnur University, Iran
}

Received: February 2011, Revised: April 2011

Online Publication: July 2011

\begin{abstract}
:
With increasing levels of globalization and international competition, managers are facing ever more complex strategic decisions. Often, foremost among these are decisions relating to the choice of entry strategy in export markets. Selection of an appropriate entry strategy is a critical and indispensable component of the strategic decision a firm has to make when investing overseas. The present study has been implemented with the aim of examining the impact of entry strategy on export performance of Iranian export companies. In goals and nature of research, it is based on a Descriptive Study, and in collecting data, it is on the basis of a Survey Research. Its statistical population consists of active export companies in stock market. Based on the method of judgmental, non-probable sampling (experts' choice), we chose 75 companies which cover 90 per cent of non-petroleum exports of the country as case study.

We collected the essential data through questionnaires. To analyze the data we used statistical methods of analyzing variance and regression of multi-variables. The study

\footnotetext{
${ }^{1}$ Study Case: Iranian Export Companies
} 


\section{J. S. Sadaghiani, N. Dehghan, K. Navabi Zand/ TJMCS Vol .3 No.1 (2011) 53-70}

results depict that the entry strategy affects the export performance of the export companies. Also, the variable share of entry strategy in anticipation and changes in export performance of the export companies is approximately $48 \%$.

KeyWords: entry strategy, export performance, Iranian export companies

\section{Introduction:}

Companies enter international competitions because of different motives such as gaining global reputation, assurance of long term growth, increase of profitability, reaping the economy of scale and for other reasons such as saturation of internal market, intensity of competition in internal market and pressure of governmental rules and regulations. In international competition, a proper and creative entry strategy guaranties a long term presence in the market and leads to the success of the company in international markets. Those companies, which tend to enter international markets, must decide about the type of entry strategy and its effect on foreign operation of the company (Cateora and Graham, 2002). Further, Firms operate in increasingly dynamic and turbulent environments characterized by intense competition, uncertain market conditions, faster technological changes and shorter product life cycles. Under these circumstances, the successful introduction of new products into the market becomes a critical factor for the survival and growth of companies. Effective new product development and commercialization is therefore a challenging task, and several studies have verified that the entry or launch strategy is a key determinant of the success or failure of product innovations (Pinto, Escudero and Cillán,2007). Some researchers believe that apart from the motive of companies for entering foreign markets, improvement of export performance is their main concern (Cavusgil, Zou and Naidu ,1993). Entry strategy is one of the most fundamental and main factors in appointing export performance (Zou and Stan, 1998). Although in previous researches an emphasis was put on the correlation and effect of entry strategy on export performance of companies, little study has been done on it.

International entry mode research is important because the chosen entry mode has significant implications for performance (Brouthers, 2002). It determines whether a company has full control over the foreign unit or has to share control with a partner (Arregle et al., 2006). In addition, once established, the mode of entry is difficult to change, because it has long-term consequences for the company (Brouthers and Hennart, 2007). Given its high relevance, numerous empirical studies have addressed the entry mode decision (see the overviews by Sarkar and Cavusgil, 1996; Brouthers and Hennart, 2007; Canabal and White, 2008). Modes of entry into international markets are the third most researched field in international management (Werner, 2002).

On the other hand, research on figures and statistics of Iranian's non-petroleum export items illustrates that international trade balance of our country has always been negative and the amount of our non-petroleum export has been less than that of the import (www.tpo.ir). Despite the role and importance of non-petroleum export items in export leap strategy and economic, social and cultural development plans in the country, little study has been conducted in this domain. Majority of studies are done in macro level that focuses on the government role in export. Few researches in country have been on micro level that focuses on company's level. Therefore, this study focuses on export companies in 


\section{J. S. Sadaghiani, N. Dehghan, K. Navabi Zand/ TJMCS Vol .3 No.1 (2011) 53-70}

Iran to answer this fundamental question that how the market entry strategies can affect export performance of export companies.

\section{Literature Review:}

Internationalization is the process of increasing the accumulation of knowledge in markets and institutions abroad. It has been observed that firms start the internationalization process by exporting products to culturally similar countries. However, other researchers argue that the longer a firm waits to initiate international activities, the more difficult it will be to grow internationally (Sharma and Blomstermo, 2003). Internationalization can be perceived as a part of the ongoing strategy process of most business firms. The main differences between internationalization and other types of strategy processes are as follows: first, when products, services or resources are to be transferred across national boundaries, the firm has to select the country where or with whom the transactions should be performed. Secondly, the firm has to select the international exchange transaction modality, i.e. a foreign market entry strategy (Andersen and Buvik, 2002). This paper concentrates on market entry strategy, because one of the critical decisions in that internationalization process is the choice of an entry strategy (Quer, Claver and Andreu, 2007).

Entry strategy is the method used by a company to start doing business in a foreign country (shama, 2000). Entry strategy is an institutional arrangement that makes possible the entry of firm's products, technology, human skills, management, or other resources into a foreign country (Karkkainen, 2005). Many forms of market entry strategy are available to firms to enter international markets. One classification first distinguishes between equity and non-equity modes. Equity modes involve firms taking some degree of ownership of the market organizations involved, including wholly owned subsidiaries and joint ventures. Non equity modes do not involve ownership and include exporting or some form contractual agreements such as licensing or franchising (Wilkinson and Nguyen, 2003). Also, Caves (1982) identified four basic ways to expand internationally, from the lowest to the highest risk: (1) exporting; (2) licensing and franchising; (3) strategic alliances; and (4) wholly owned foreign subsidiaries.

Cateora and Graham (2002) stated there are six basic strategies for entering a new market: export/import, licensing and franchising, joint venturing, consortia, partially-owned subsidiaries, and wholly-owned subsidiaries. Generally, these represent a continuum from lowest to highest investment and concomitant risk-return potential. In choosing a particular strategy, a company constructs a fit between its internal corporate risk "comfort level" and the externally-perceived risk level of the target entry market. Two companies may perceive different risks as they evaluate the same market and therefore choose different entry modes. Two companies also may perceive the same risks in a country but still choose different strategies because of their firm's differing tolerances of risk. More specifically, the different market-entry strategies can be encapsulated as follows (Cateora \& Graham 2002, pp. 325-335).

The initial classification of different international entry modes is founded on two separate characteristics; (1) the location of manufacturing facilities, and (2) the percentage of ownership the firm desire in foreign investment. Entry in the foreign markets can occur in two ways based on the location of the manufacturing facilities. The firm can either export 


\section{J. S. Sadaghiani, N. Dehghan, K. Navabi Zand/ TJMCS Vol .3 No.1 (2011) 53-70}

its products to the target country from production facilities outside that country (exporting strategies), or the firm can transfer its resources in technology, capital, human skills, and enterprise to the foreign country, where they may be sold directly to users or combined with local resources to manufacture products for sale in local market (non exporting strategies). The second characteristic (percentage of ownership) offers three different options; none, partly or wholly owned investment (Karkkainen, 2005).

\section{1) Export Strategies:}

Numerous firms choose exporting for an international entry mode as a strategic alternative that maintains effort and resources while still taking advantage of foreign opportunities (Czinkota et al, 1992). The exporting can become an international learning experience (Root, 1994). Many firms choose export for their first international entry mode. This is the easiest and most low risk way to enter foreign markets. It needs the least facility allocation and has the lowest changes in the country marketing programs (Kotabe and Helsen, 2000; Onkvisit and Shaw, 1993).

A firm using exporting strategies usually achieves certain benefits like, the rapidity of international market entry, and not required investment in establishing operations in the host country. Especially direct exporting offers for a firm a low risk and simple way to begin its international process and meet the demand and challenges. In addition, in exporting alternative the company and management commitment is usually small (Hitt et al, 2003: Luostarinen and Welch, 1990). Export strategies are divided into two categories: direct export strategy and indirect export strategy.

\section{Direct Export Strategy:}

In direct importing firms are in interrelationships with foreign customers and markets. The end result of exporting is the same whether the activities are direct, own or indirect (Karkkainen, 2005). Companies, which are urged to export by foreign customers, usually use this strategy. In this strategy, the company is connected to one or more sales agents in the country. Companies, which accept all necessary liabilities to sell their products in the target country, can attempt direct export strategy. Therefore, it requires a high level of expertise in international marketing. The advantages of this strategy are more sales, control, market information, experience and specialty of the company in export, while the drawback is more cost. Different methods of direct export are: export agents, mobile sales agents, sales branches, internal export department, and mail order (Albaum et al, 2002).

\section{Indirect Export Strategy:}

In indirect involvement firms participate in international businesses trough an intermediary and do not deal with foreign customers or firms (Karkkainen, 2005). In this strategy the company sends its products to foreign customers through intermediaries in its country (Kotabe and Helsen, 2000). In other words, a company employs indirect export strategy when its products are sold in foreign markets without any special activities inside the company. In fact, in this strategy the company does not involve in international marketing in real sense. This strategy is more common among companies which have recently decided to export. The methods of indirect export are: using commercial companies, using export management companies, cooperation in export and distribution 


\section{J. S. Sadaghiani, N. Dehghan, K. Navabi Zand/ TJMCS Vol .3 No.1 (2011) 53-70}

(Piggyback Marketing), intermediaries and export agents, and export cooperative organizations (Albaum et al, 2002).

\section{2) Non Export Strategies:}

It means the company produces its export products in other countries and exports them to international markets (Dehghan, 2008). Types of non-export strategies consist of:

\section{Strategic Alliances:}

In a strategic alliance, organizations pool or share their resources and expertise with other firms and the parties share the rewards or risks of starting a new venture (ling et al, 2005). In this strategy, the company uses methods such as licensing, franchising, contractual production, and joint investment for entering international markets. In licensing and franchising, the company enters the foreign market without investment. The joint investment happens when a company requests to share in the stock of a foreign company (Dehghan, 2008). A joint venture involves constantly sharing equity and risks and also participation in management between partners forming a long lasting, profit seeking relationship (Karkkainen, 2005). The advantages of joint venture are saved capital and less restricted resources for foreign country operations. Also the risks involved in international market entry are smaller and through join venture the firm acquires highly important resources, like local knowledge and experiences (Luostarinen and Welch, 1990; Root, 1994). Joint ventures permit closer relationships with local government and other organizations such as labor unions. Joint ventures make also possible to minimize risk of exposing long term investment capital, while at the same time maximizing the leverage on the capital that is invested (Czinkota et al, 1992).

\section{Foreign Direct Investment:}

In this strategy, an international company handles all production activities in a foreign country and owns $100 \%$ of the company. This can happen in two ways: firstly, it can buy an active company; secondly, it can establish a new company (Dehghan, 2008). When firms choose to set up wholly owned foreign subsidiaries as the entry mode, they are establishing operations in a foreign country without direct involvement of firms from that country (ling et al, 2005). The core advantage of the foreign direct investment for the firm is the maintained control over the technology, marketing, and distribution of its products (Hitt et al, 2003). The disadvantages of the Greenfield investment are usually often complex establishing process and potential high costs. Establishing new wholly owned subsidiary takes a lot of time, and thus is not appropriate for rapid entering in foreign markets. Establishing the Greenfield investment needs also the greatest contribution of knowhow of all the international market entry alternatives (Karkkainen, 2005).

\section{Entry strategy selection:}

The theories of international production are commonly employed as the basis to analyze entry strategy selection of international firms. Many mono disciplinary theoretical frameworks, for example, Hymer's market imperfections theory (Hymer, 1960), the transaction costs theory (Williamson, 1975; Anderson and Gatignon, 1986), the internalization theory (Buckley and Casson, 1976), the strategic behavior approach (Kogut, 1988), and the resource-based approach (Wernerfelt, 1984), have tried to explain the 
choice of an optimal entry mode into a foreign market by international firms from one specific perspective only. Nevertheless, Andersen (1997) argues that a firm's entry strategy choice involves many factors and that one single theoretical perspective is not adequate to provide a comprehensive explanation. To tackle this complex decision-making process of entry strategy selection, an eclectic approach that compares various factors simultaneously is obviously more appropriate. An attempt to integrate different theoretical approaches into an eclectic framework is made by Dunning (1980; 1988; and 1995). According to Dunning's eclectic model, the firm's decision to enter a foreign market and the choice of a market entry mode (direct investment, contractual resources transfers or exports) depends upon the possession of (1) ownership-specific, (2) location-specific, and (3) internalization advantages. His eclectic paradigm helps analyze why firms choose foreign production rather than exports or transferring technology overseas. However, Dunning's model is not to distinguish the choice between a wholly owned subsidiary and a joint venture once the firm has decided to invest directly in a foreign country (Moon, 1997).

Usually, selection of entry strategy involves two steps: (1) determining the location of production facilities, and (2) deciding the firm's level of involvement in, or control of, the operations of the foreign subsidiary. In Step 1, a manufacturing business or a hard service business chooses between exporting and production in the target foreign market. In Step 2, manufacturing business or a hard service business chooses between full-control or highinvolvement modes and shared-control or low-involvement modes (Ekeledo and Sivakumar, 1998).

Many researchers have suggested that entry strategies may be differentiated according to the level of resource commitments and control (Peinado and Barber, 2006). Also, many often conflicting forces are influencing a company's choice of entry strategy. Factors influencing in entry mode decisions can be divided for external and internal factors. External factors include target country market factors, target country environmental factors, target country production factors and home country factors. Internal factors affecting in the entry mode decision are company product factors and company resource factors (Root 1994; Koch, 2001)

\section{Performance:}

A fundamental debate in strategic management and international marketing research is questioning about the performance, especially when the companies involve in international performance (Florin and Agboei, 2004). An accurate understanding of the crucial link between international strategy and performance is especially important in the face of world markets that are increasingly global. Consequently, international marketing research has moved from being descriptive - studying the differences between exporters and non-exporters - to providing performance explanations (shoham and kropp, 1998). In today's complex business world, performance is an indispensable guide for any company analyzing its level of success, in both the domestic and international arenas. Assessing export performance is quite a complex task, as export performance can be conceptualized and operationalized in many ways. Broadly speaking, the literature considers three aspects of export performance: financial, strategic, and that of performance satisfaction (Lages and Montgomery 2004). Although considerable progress has since been made, research remains underdeveloped. Defining and understanding performance is problematic, especially in terms of identifying uniform, reliable, and valid performance measures (Katsikeas, Leonidou and Morgan, 2000). Export performance is the dependent variable in 


\section{J. S. Sadaghiani, N. Dehghan, K. Navabi Zand/ TJMCS Vol .3 No.1 (2011) 53-70}

the simplified model and is defined as the outcome of a firm's activities in export markets. There are two principal ways of measuring export performance: economic (financial measures such as sales, profits, and market share) and noneconomic (nonfinancial measures relating to product, market, experience elements, etc.) . Most background and intervening variables were associated with economic measures of performance, particularly export sales intensity (export-to-total sales ratio), export sales growth, and export profitability (Katsikeas, Leonidou and Morgan, 2000). Also, Export performance, a widely studied construct, refers to the outcomes of a firm's export activities, although conceptual and operational definitions vary in the literature (Calantone, 2005)

\section{Entry Strategy and export performance:}

The choice of entry mode has become a crucial strategy decision for firms wishing to enter international markets, as it will have an important influence on their future business success (Peinado and Barber, 2006). Market entry strategies affect business performance in the context of manufacturing industries (Kirca, 2005). Choosing the right entry strategies is one of the key points in international marketing. These strategies have an effect on performance and duration of it through determining the method and allocating essential and sufficient resources (Ekeledo \& Sivakumar, 1998). Entry mode performance is defined in terms of efficiency or profitability. Non profit motives, such as resource and knowledge development or strategic moves against competitors, are assumed to be reflected in long term profit. Profitability depends on costs and revenues (Wilkinson and Nguyen, 2003). Furthermore, some of the researches indicate that entry strategies affect export performance by determining the control level, risk level and company share in foreign markets and end up with the success or failure of the company (Kouck et al 2003, Karkkainen 2005, Shi et al 2002).

Previous studies have generally neglected the link between exporting and performance and survival. An exception is the study conducted by McDougall and Oviatt (1996). Their longitudinal study of 62 new manufacturing firms in the USA engaged in the computer and communications industries revealed that ventures that had increased international sales, compared to those that had not, exhibited superior performance in terms of both relative market share and return on investment (ROI). However, their study was conducted over only a 2-year period and focused solely upon a relatively small sample of manufacturing firms. Westhead (1995), during his cross-sectional study of new firms in Great Britain, focused upon the performance of firms engaged in manufacturing and producer services activities. He found that exporting firms recorded significantly higher levels of absolute growth since the businesses had received their first orders than did non exporting firms (Westhead et al, 2001).

\section{Conceptual Model}

Based on the foregoing literature review it is possible to propose a model of entry strategy and export performance as shown in Figure 1. This figure concentrates on the relationship between entry strategies and export performance. Further, in most researches in international business, international experience and the firm size are considered as control variables. Therefore, in this study also these two variables are considered as control variables. The relationship between firm size and export performance has been studied 


\section{J. S. Sadaghiani, N. Dehghan, K. Navabi Zand/ TJMCS Vol .3 No.1 (2011) 53-70}

frequently in the international marketing literature. There is general consensus in the literature that firm size is positively related to the firm's propensity to export (Verwaal, and Donkers, 2002). Also, firm size affects entry strategy. Horst (1972) already argued that, considering the inherent risks and fixed costs, the proneness to invest abroad must increase with the dimension of the firm. Besides, greater size implies greater availability of financial and managerial resources, which makes it easier to set up full-ownership subsidiaries (Tallman \& Fladmoe-Lindquist, 2002). In keeping with this, a large part of the empirical research has observed that firm size correlates positively with the degree of commitment assumed with the entry mode (Quer, Claver and Andreu, 2007).

In relation to the firm's international experience, the more internationally competent a firm is the more likely it is that standardization alone will not lead to optimal results. A competent firm, because of its international experience knows the differences in environmental conditions and is more likely to select the most attractive market for the venture and adapt the marketing strategy to accommodate the specific needs of the market (Cavusgil and Zou, 1994). Experience in international business complements abundant resources. Relative corporate experience, often reflected in the ratio of foreign sales to total sales, number of foreign markets currently served, and knowledge of the host country, influences entry mode choice. Empirical evidence shows that the preference for sole ownership increases with cumulative international experience (Ekeledo and Sivakuma, 1998).

A firm with limited international experience that enters foreign markets is likely to use a low- involvement mode of operation, such as exporting, to gain experience before getting involved in equity investment. However, when Erramilli (1991) examined the impact of international experience on the entry mode choice of services, he found a U-shaped relationship between international experience and the tendency to adopt sole ownership. Some explanations for that finding were offered in our preceding discussion. The important point here is that services in general tend to favor a sole ownership venture as they accumulate extensive international marketing experience. Furthermore, the U-shaped phenomenon is most likely to apply to soft services. Because soft services must locate production in the local market, inexperienced soft services are the ones most likely to adopt sole ownership the first time they enter a foreign market, especially if that market is culturally similar to their domestic market. Sole ownership gives soft services rapid and worthwhile international marketing experience. Hard services, in contrast, are likely to follow a linear pattern, like manufactured goods, adopting exporting with inexperience and sole ownership with extensive experience (Ekeledo and Sivakuma, 1998). 
Figure1- Research Conceptual Model

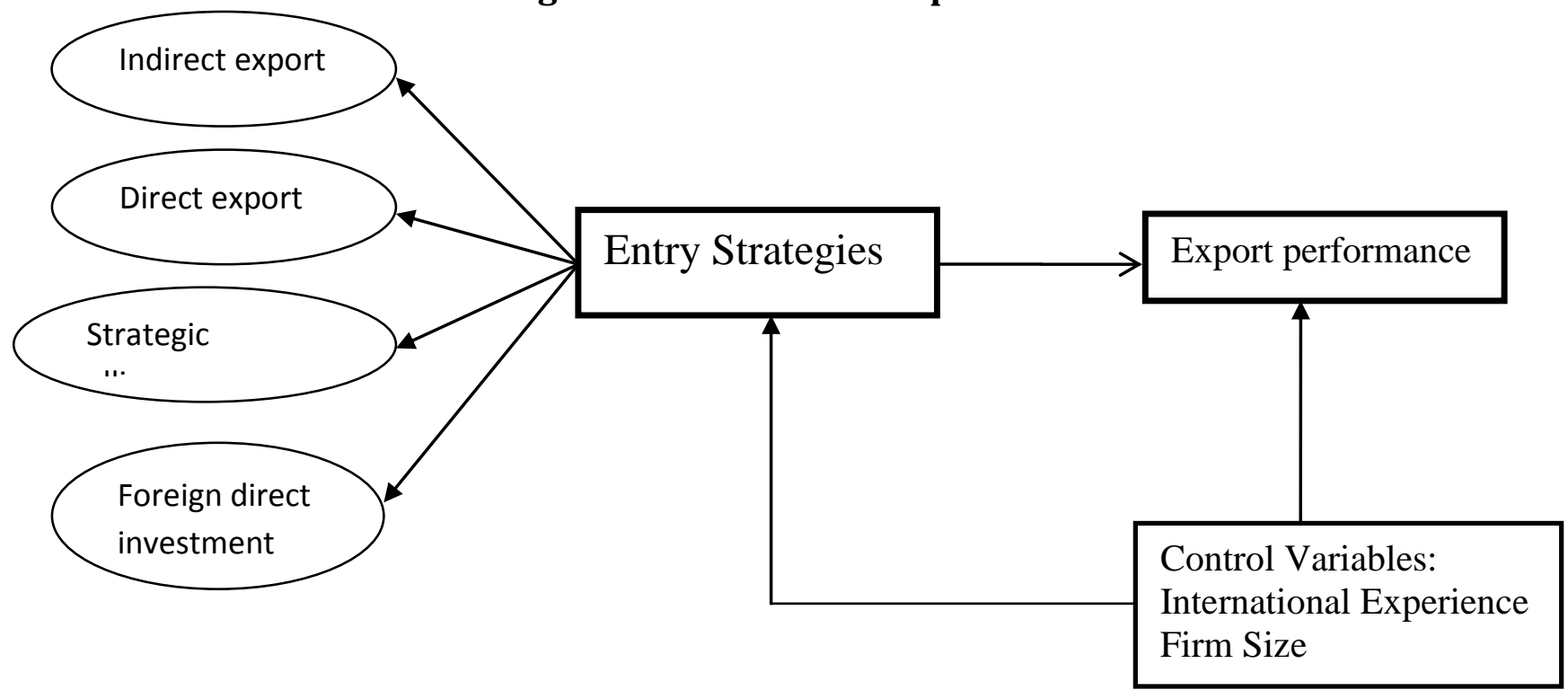

Research Methodology

Based on nature and goals, this research is Descriptive. This is categorized in Descriptive format because Descriptive Research studies present condition and explains the results; moreover, the researcher cannot change any independent variables, but he can use the results to suggest, design a model, or design a system (Khaki, 2000). The current research is a Survey one in the method of data collection. The statistical population of the research is the Iranian export companies active in stock market which were present in foreign markets between 2006 and 2010. The statistical sample of the research consists of Iranian export companies active in stock market which were present in foreign markets between 2006 and 2010 and their export performance was not less than \$1 million. Based on judgmental, non-probability sampling method (experts' choice), 75 companies were chosen as final statistical sample which covered 95\% of the country non-petroleum export. Because 14 companies either did not want to cooperate in research or their questionnaires were incomplete, the analysis was conducted on 61 companies which covered more than $82 \%$ of the total export of the Iranian country.

\section{Questionnaire Validity and reliability}

In this research, to evaluate the validity of the designed questionnaire, a copy was given to some management professors who were familiar with international marketing and export issues to express their ideas about the accuracy and clearness of the questions. After necessary amendments, they approved the validity of the questionnaire. For determining questionnaire reliability, we used Cronbach Alpha. The total sum of the calculated Alpha is 0.919 which shows the high reliability of the designed questionnaire.

\section{Descriptive Analysis}

In each statistical analysis, the first step is to manifest and summarize the data. Table 1 describes the research pattern. 
Table 1- pattern description of the research

\begin{tabular}{|l|c|c|c|}
\hline $\begin{array}{c}\text { Pattern Description based } \\
\text { on }\end{array}$ & Choice & frequency & Percent \\
\hline \multirow{3}{*}{ Number of Employees } & $\begin{array}{l}\text { Fewer than 100 } \\
\text { people }\end{array}$ & 13 & 21.31 \\
\cline { 2 - 4 } & $100-500$ & 37 & 60.65 \\
\cline { 2 - 4 } & More than 500 people & 11 & 18.02 \\
\hline \multirow{3}{*}{ Age of the Samples } & Under 35 & 28 & 45.9 \\
\cline { 2 - 4 } & More than 50 & 27 & 44.26 \\
\cline { 2 - 4 } & Female & 21 & 3.83 \\
\hline Gender of the Samples & Male & 40 & 65.57 \\
\hline \multirow{3}{*}{ Education of the Samples } & Associate Diploma & 3 & 4.91 \\
\cline { 2 - 4 } & Bachelor's & 34 & 55.73 \\
\cline { 2 - 4 } & Master's & 24 & 39.34 \\
\hline
\end{tabular}

\section{Inferential Analysis}

To determine the impact of entry strategy on export performance by considering covariate variables of international experience and firm size, the analysis of variance is used. It is the method that analyzes the simple and interactive impacts of two or more independent variables on one dependent variable. In other words, in this analysis one or more independent, semi-independent or interactive variables change to create deviation of dependent variable. In this design, the number of ways, values, or issues that an item changes by is called its levels (Hooman, 2008: 488). The levels of entry strategy factor based on the degree of involvement in international markets are very high, high, low and very low. The following statistical hypotheses were made to assess the entry strategy in export performance:

Zero Hypotheses: The average of export performance of companies with different entry strategies is the same.

Alternative Hypothesis: The average of export performance of companies with different entry strategies is different.

Table 2 illustrates the assessment results of the effects of entry strategy on export performance. It shows descriptive statistics and the table of assessment of effects in midtests (model test).

Table 2- Descriptive Statistics of Entry Strategy Variable

\begin{tabular}{|c|c|c|c|}
\hline $\begin{array}{c}\text { Entry Strategies } \\
\text { (Based on } \\
\text { International Markets } \\
\text { involvement) }\end{array}$ & Average & Std. Deviation & $\begin{array}{c}\text { Number of } \\
\text { Companies }\end{array}$ \\
\hline $\begin{array}{c}\text { Very low } \\
\text { (Indirect Export) }\end{array}$ & 31.7375 & 21.6523 & 16 \\
\hline low (Direct Export) & 45.4965 & 34.29192 & 26 \\
\hline high (Alliances) & 15.7643 & 13.97142 & 7 \\
\hline
\end{tabular}




\begin{tabular}{|c|c|c|c|}
\hline $\begin{array}{c}\text { Very high } \\
\text { (Direct Investment) }\end{array}$ & 86.9523 & 35.05938 & 21 \\
\hline
\end{tabular}

Dependent Variable: Export Performance (\$million)

Based on the table 1, the average of export performance for the companies which use indirect export entry strategy is $\$ 31.73$ million. For those which use direct export entry strategy it is $\$ 45.49$ million. For those which use strategic alliances entry strategy it is $\$ 15.76$ million and for those which use direct investment entry strategy it is $\$ 86.95$ million. This analysis depicts the difference in export performance of companies based on their entry strategy.

Tests of Between-Subjects Effects (Model Test)

Tests of Between-Subjects Effects (Model Test) have indicated in table 3.

Table3. Tests of Between-Subjects Effects (Model Test)

Dependent variable: export performance

\begin{tabular}{|c|c|c|c|c|c|}
\hline Source & $\begin{array}{c}\text { Type III Sum of } \\
\text { Squares }\end{array}$ & $\mathrm{df}$ & $\begin{array}{c}\text { Mean } \\
\text { Square }\end{array}$ & $\mathrm{F}$ & Sig. \\
\hline Corrected Model & $24178.634(\mathrm{a})$ & 4 & 9792.158 & 14.231 & .000 \\
\hline Intercept & 42553.169 & 1 & 3353.669 & 13.1581 & .008 \\
\hline $\begin{array}{c}\text { International } \\
\text { experience }\end{array}$ & 13.388 & 1 & 17.320 & 0.597 & .003 \\
\hline firm size & 3181.377 & 1 & 4701.651 & 15.603 & .001 \\
\hline Entry strategy & 16493.482 & 2 & 5021.991 & 14.579 & .000 \\
\hline Error & 25888.239 & 32 & 652.757 & & \\
\hline Total & 88129.655 & 61 & & & \\
\hline Corrected Model & 86171.15 & 60 & & & \\
\hline
\end{tabular}

a R Squared $=.562$ (Adjusted R Squared $=.531$ )

The results of table 3 are the most important for interpreting of factorial variance analysis. This test shows the significance or non-significance of total model and also the separate effect of each independent variable on dependent one. Table 3 can be described as follows:

1- As the significant level of the corrected model and the width from the source are less than 0.05 , the model is significant.

2- The effect of International experience variable (with statistic $\mathrm{F}=0.597$ and significance level of .003) on export performance is significant. That means, statistically, export performance is different in different levels of international experience. That is international experience affects export performance.

3- The effect of firm size variable (with statistic of $F=12.203$ and significance level of 0.001) on export performance is significant. That means, statistically, export performance in different levels of firm size is not the same. That is firm size affects export performance.

4- The main effect of entry strategy variable (with statistic of $\mathrm{F}=15.603$ and significance level of 0.501 ) on export performance is significant. That means, statistically, export performance varies in different entry strategies and is not the 


\section{J. S. Sadaghiani, N. Dehghan, K. Navabi Zand/ TJMCS Vol .3 No.1 (2011) 53-70}

same. In other words, various firms with different entry strategies have different export performances.

5- The Adjusted R Squared is equal to 0.531 that shows the three variables of international experience, firm size and entry strategy could make $53.1 \%$ of export performance variance together; therefore, $46.9 \%$ of export performance variance of the companies under study in this research is affected by items and variations which are not studied in this research.

\section{Multi-variable Regression Test}

Regression analysis is used for finding the share of independent variables in anticipating dependent variable. In regression analysis the aim is to anticipate the changes in dependent variable considering the changes in independent variables. Using multi-variable regression, the researcher can study the existing linear relation between a set of independent variables and a dependent variable in a way that the existing relationship inside independent variables is also considered. Multi-variable regression analysis is completely suitable to study the effects of some independent variables on a dependent variable. To use multi-variable regression, the following assumptions are necessary (kerlinger and Pedhauser, 2009):

1)Distribution of dependent variable data should be normal. In this research, to make sure that the data of export performance variables are normally distributed, we used One-Sample Kolmogorov-Smirnov Test. The results approve that export performance variable is normal. 2) The dependent variable variance in all points of independent variables is the same. To test the equality of variances in this study we used statistical testing of Leven in which the equality of variances is observed. In analyzing multivariable regression there are various methods. But one of the most common methods to anticipate dependent variable based on independent variables is to analyze the multivariable regression in step by step method. In this method the SPSS software omits the meaningless variables which have no effect on the model in each phase from the model. The results of are presented in table 4 .

Table 4- multi-variable regression in step by step method

\begin{tabular}{|c|c|c|c|c|c|}
\hline & $\begin{array}{l}\text { Independent } \\
\text { Variables }\end{array}$ & $\begin{array}{l}\text { Dependent } \\
\text { Variable }\end{array}$ & B & sig & Test Result \\
\hline $\begin{array}{l}\text { Regression } \\
4^{\text {th }} \text { phase }\end{array}$ & $\begin{array}{l}\text { Entry Strategy } \\
\text { Firm Size } \\
\text { International } \\
\text { Experience }\end{array}$ & $\begin{array}{c}\text { Export } \\
\text { performance }\end{array}$ & $\begin{array}{l}0.483 \\
0.215 \\
0.098\end{array}$ & $\begin{array}{l}0.000 \\
0.000 \\
0.003\end{array}$ & $\begin{array}{c}\mathrm{H} 1 \\
\text { reception }\end{array}$ \\
\hline
\end{tabular}

Based on table 4, the function of multi-variable regression of export performance in accordance with entry strategy dimensions and firm size of Iranian export companies is as follows:

$\mathrm{Y}=0.483 \mathrm{X} 1+0.215 \mathrm{X} 2+0.098 \mathrm{X} 3$

Y: export performance 
$\mathrm{X} 1$ : entry strategy, $\mathrm{X} 2$ : firm size, $\mathrm{X} 2$ : international experience

The interpretation of the regression function is that the entry strategy, firm size, and international experience shares in predicting firms' export performance active in stock market are $0.483,0.215$, and 0.098 respectively. In other words, for each unit change in entry strategy, firm size, and their international experience, their export performance changes minimum $0.483,0.215$, and 0.098 relevantly. In total, we can say that entry strategy anticipates around $48 \%$ of changes in export performance variance and the rest $42 \%$ is anticipated through other factors which have not been studied in this research.

Also, the results of correlation between research variables show in figure 2 .

\section{Figure2- the results of correlation between research variables}

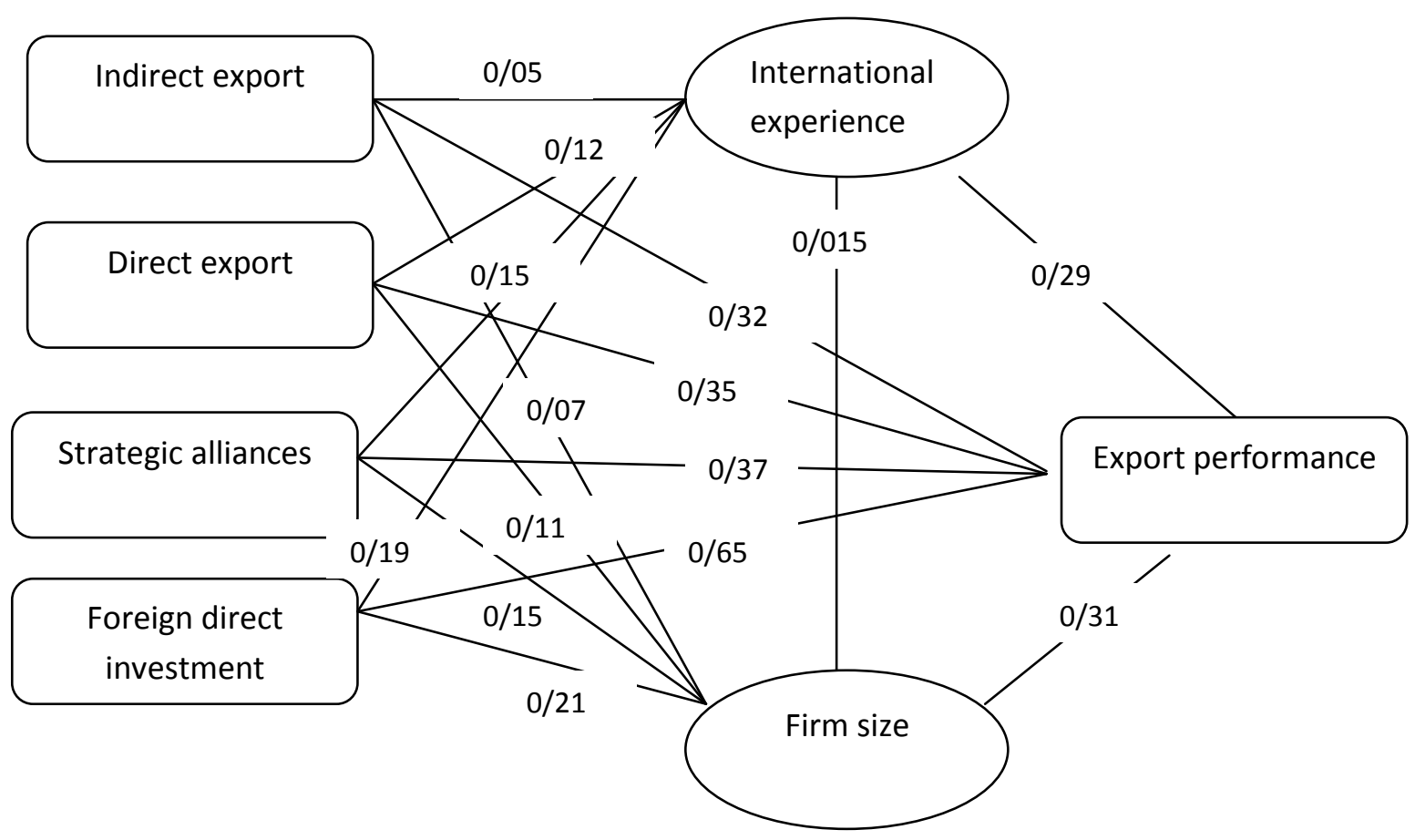

\section{Conclusion and Suggestions:}

Entry strategy to international markets is one of the main elements in international marketing strategies of the companies for competing in international markets which plays a vital role in their success or failure (Dehghan, 2010). Hence, this research is implemented with the aim of studying the effects of entry strategy of export companies active in stock markets on their export performance. The results indicate that entry strategy affects export performance of Iranian export companies and this effect is higher on those companies which use entry strategy with foreign direct investment rather than the ones which use entry strategies with indirect export, direct export and strategic alliances. One of the reasons is that about 20 companies out of the statistical 


\section{J. S. Sadaghiani, N. Dehghan, K. Navabi Zand/ TJMCS Vol .3 No.1 (2011) 53-70}

population are engineering and technical service exporters which have more export performance in comparison with the other industry exporters. These companies usually enter in export markets with direct investments and have good output. Therefore, it is recommended to Iranian export companies, especially engineering and technical export companies, to use entry strategy with foreign direct investment in order to improve their export performance and international sales. As this strategy has the highest level of involvement, commitment, and participation to international markets, it requires the highest level of expertise and training of export and international marketing. As a result, it is advised that before selecting and using of entry strategy with direct investment, Iranian export companies run the courses of International marketing and export for their marketing and sales staffs and managers.

Also, the results show that the more experts the companies use in export markets, the more their export performance is. In addition, the results depict that international experience of companies affect their export performance, so it is proposed that Iranian export companies develop future export performance by making regular presence in international markets and attaining more experience and know-how.

As the results demonstrate that the share of entry strategy in anticipation of export performance of companies active in stock market is $48 \%$ and approximately $42 \%$ of export performance of the companies relate to other factors, it is suggested that a separate research is done to study share of other variables which affect export performance of export companies.

\section{References:}

1. Albaum Gerald et al, (2002), International Marketing and Export Management, Prentice Hall, pp.248-249

2. Andersen, 0. (1997), 'Internationalization and Market Entry Mode: A Review of Theories and Conceptual Frameworks', Management International Business Studies, Vol.17, No.2, pp.1-26.

3. Andersen 0. and Buvik A. (2002). Firms' internationalization and alternative approaches to the international customer/market selection. International Business Review. Vol. 11 pp. 347-363

4. Arregle, J.-L., Hébert, L., Beamish, P., (2006).Mode of international entry: the advantages ofmultilevelmethods. Management International Review. Vol. 46 No.5 Pp. 597-618

5. Brouthers, K., (2002). Institutional, cultural and transaction cost influences on entrymode choice and performance. Journal of International Business Studies. Vol. 33 No.2 pp. 203-221

6. Brouthers, K., Hennart, J.-F., (2007). Boundaries of the firm: insights from international entry mode research. Journal of Management. Vol.33, No.3. pp. 395425.

7. Buckley, P. and Casson, M. (1976), The Future of the Multinational Enterprise. London: Macmillan. 


\section{J. S. Sadaghiani, N. Dehghan, K. Navabi Zand/ TJMCS Vol .3 No.1 (2011) 53-70}

8. Calantone, Roger et al (2005). The influence of internal and external firm factors on international product adaptation strategy and export performance: A three-country comparison. Journal of Business Research. Vol. 59. Pp. 176 - 185

9. Calof L Jonathan (1994). The Relationship between Firm Size and Export Behavior Revisited. Journal of international business studies. pp.367-387

10. Canabal, A., White, G.O., (2008). Entry mode research: past and future. International Business Review. vol. 17, pp. 267-284.

11. Cateora \& Graham (2002), International Marketing,11 Edition, McGraw-Hill

12. Caves, R.E. (1982) Multinational enterprises and technology transfer, in Rugman, A.M. (ed.) New Theories of the Multinational Enterprise, St Martin's Press, New York, pp. 254-79.

13. Cavusgil, S Tamer, Zou, Shaoming, Naidu, G M (1993). Product and promotion adaptation in export ventures: An empirical investigation. Journal of International Business Studies. Washington: Third Quarter. Vol. 24. pp. 479-507

14. Czinkota, M. R., Rivoli, P., Ronkainen, I. A., (1992). International Business, The Dryden Press, pp. 268-289

15. Dunning, J.H. (1980), 'Toward an Eclectic Theory of International Production: Some Empirical Tests', Journal of International Business Studies, Vol.11, pp.9-31.

16. Dunning, J.H. (1988), 'The Eclectic Paradigm of International Production: A Restatement and Some Possible Extension', Journal of International Business Studies, Vol. Spring, pp.1-31.

17. Dunning, J.H. (1995), 'Reappraising the Eclectic Paradigm in An Age of Alliance Capitalism', Journal of International Business Studies, Vol.25 , No.3, pp.461-91.

18. Dehghan Nabi allah (2007). Study and Classification of Entry Strategies to International Markets. $2^{\text {nd }}$ International Conference of Strategic Management. October- November

19. Dehghan Nabi allah (2010). A Model of Export Performance Improvement: The Effect of Strategic Fit between International Marketing Strategy and Organizational Contextual Dimensions and international marketing subsystems on Export Performance. PH.D Thesis. Faculty of business management. Allame Taba Tabaee University

20. Ekeledo \& Sivakumar (1998), Foreign Market Entry Mode Choice of Service Firms: A Contingency Perspective, Journal of the Academy of Marketing Science

21. Florin Juan, O. Ogbuehi Alphonso (2004). Strategic Choice in International Ventures: A Contingency Framework Integrating Standardization and Entry-Mode Decisions. The Multinational Business Review. Vol.12 No. 2. pp.83-109

22. Hitt, M. A., Ireland, R. D., Hoskisson, R. E., (2003). Strategic Management: Competitiveness and Globalization, SouthWestern, p.258 - 287

23. Hooman Heydar Ali (2008). Statistical Deduction in Behavioral Studies. $4^{\text {th }}$ edition. Tehran. Samt Publication

24. Horst, T. (1972). Firm and industry determinants of the decision to invest abroad: An empirical study. The Review of Economics and Statistics, vol.3, 258-266.

25. Hymer. S. (1960 and 1976), The International Operations of National Firms: A Study of Direct Investment. Cambridge, MA: MIT Press.

26. Khaki Gholamreza (2000). Management Research Methodology. Tehran. Scientific Publication Center, Azad University 


\section{J. S. Sadaghiani, N. Dehghan, K. Navabi Zand/ TJMCS Vol .3 No.1 (2011) 53-70}

27. Kärkkäinen Aleksi (2005), Selection of International Market Entry Mode, Seminar in Business Strategy and International Business

28. Katsikeas Constantine S., Leonidou Leonidas C. and Neil A. Morgan ( 2000). FirmLevel Export Performance Assessment: Review, Evaluation, and Development. Journal of the Academy of Marketing Science pp. 28; 493

29. Katsikeas Constantine S et.al (2006). Strategy Fit and Performances of International Marketing Standardization. Strategic Management Journal.vol.27. pp. 867-890

30. Kerlinger Fred Nicole and Pedhazer Elazer (2009). Multi-variable Regression in Behavioral Study. Translated by Hassan Saraei. Tehran. Samt Publication

31. Kigan Varen J (2001). Global Marketing Management. First Edition. Tehran. Cultural Research Bureau

32. Kock et al (2003). Project Business as a Distinct Market Entry Mode. IMP Conference in Lugano, Switzerland

33. Kogut, B. (1988), 'Joint Ventures: Theoretic and Empirical Perspectives', Strategic Management Journal, Vol.9, pp.319-32.

34. Kotabe \& Helsen (2000). Global Marketing Managemen. John Wiley \& Sons, Inc.

35. Kirca Ahmet H. (2005). The impact of mode of operation on sales performance in international services. Journal of Services Marketing. Vol.19 No.1 pp. 39-46

36. Lages Luis Filipe, Montgomery David B.( 2004). Export performance as an antecedent of export commitment and marketing strategy adaptation Evidence from small and medium-sized exporters. European Journal of Marketing.Vol. 38.No. 9/10. pp. 1186-1214

37. Ling Florence, Williams c and cuervo (2005), Entry and business strategies used by international architectural, engineering and construction firms in China, Construction Management and Economics vol. 23 pp. 509-520

38. Luostarinen, R., Welch, L., (1990). International Business Operations, Kyriiri Oy, Helsinki, p.273

39. Moen Øystein (1999). The Relationship Between Firm Size, Competitive Advantages and Export Performance Revisited. International Small Business Journal. vol. 18.pp.53-72

40. Moon, H. Chang (1997), 'The Choice of Entry Modes and Theories of Foreign Direct Investment', Journal of Global Marketing, Vol.11, No.2, pp.43-64.

41. O'Cass Aron Craig Julian (2003). Examining firm and environmental influences on export marketing mix strategy and export performance of Australian exporters. European Journal of Marketing. Vol. 37. No. 3/4. pp. 366-384

42. Onkvisit \& Shaw (1993). International Marketing: analysis and strategy. second Edition, MacMillian Publishing Company

43. Peinado Esther Sanchez and Barber Jose Pla (2006). multidimensional concept of uncertainty and its influence on the entry mode choice: An empirical analysis in the service sector. International Business Review. Vol. 15. pp. 215-232

44. Pinto Javier Rodríguez, Escudero Ana Isabel Rodríguez and Cillán Jesús Gutiérrez (2007). Order, positioning, scope and outcomes of market entry. Industrial Marketing Management. Vol. 2. Pp. 1-13 


\section{J. S. Sadaghiani, N. Dehghan, K. Navabi Zand/ TJMCS Vol .3 No.1 (2011) 53-70}

45. Quer Diego , Claver Enrique, Andreu Rosario (2007) . Foreign market entry mode in the hotel industry: The impact of country- and firm-specific factors. International Business Review. Vol.5. pp. 1-15

46. Root, F. R (1994). Entry strategies for international markets, Lexington books

47. Sarkar, M., Cavusgil, T.,( 1996). Trends in international business thought and literature: a review of international marketing entry mode research: integration and synthesis. The International Executive. Vol. 38. No.6.pp. 825-847.

48. Sekaran Oma (2001). Management Research Methodologies. Translated by Mohammad Saebi and Mahmoud Shirazi. Tehran. Governmental Management Training Center Publication

49. Shama Avraham (2000). Determinants of Entry Strategies of U.S. Companies into Russia, the Czech Republic, Hungary, Poland, and Romania. Thunderbird International Business Review, Vol. 42. No.6. pp. 651-676

50. Sharma D. Deo and Blomstermo Anders (2003).The internationalization process of Born Globals: a network view. International Business Review. Vol.12. Pp. 739-753

51. Shoham, A. (1991), "Performance in exporting: a state-of-the-art literature review and synthesis and directions for future research", paper presented at the National Conference of the Academy of International Business, Miami, FL, 17-21 October.

52. Shoham, Aviv and Kropp Fredric (1998). International performance: marketing mix, planning, and their interaction. Marketing Intelligence \& Planning. Vol.16 No.2 pp.114-123

53. Shi Yi-Zheng Ho, Po-Yuk and Siu Wai-Sum (2002). Market Entry Mode Selection: The Experience of Small Hong Kong Firms Investing in China, Asia Pacific Business Review, Vol.8, No.1, pp.19-41

54. Shoham Aviv and Kropp Fredric (1998). Explaining international performance: marketing mix, planning, and their interaction. Marketing Intelligence \& Planning. vol.16. No.2. pp.114-123

55. Tallman, S., \& Fladmoe-Lindquist, K. (2002). Internationalization, globalization, and capability-based strategy. California Management Review, vol.45. No.1 pp. 116-135.

56. Venaik Sunil (1999). A Model of Global Marketing in Multinational Firms: An Empirical Investigation. PhD thesis. University of Sydney. internet

57. Verwaal, Ernst and Donkers, Bas (2002). Firm Size and Export Intensity:Solving an Empirical Puzzle. Journal of international business studies. Vol. 33. No. 3. Pp. 603-613

58. Werner, S., 2002. Recent developments in international management research: a review of 20 top management journals. Journal of Management. Vol.28. pp. 277-305.

59. Wilkinson Ian F. and Nguyen Van (2003), A Contingency Model of Export Entry Mode Performance: The Role of Production and Transaction costs, Australasian Marketing Journal . vol.11 No.3

60. Wernerfelt, B. (1984), 'A Resource-based View of the Firm', Strategic Management Journal, Vol.5, pp.171-80.

61. Westhead Paul et al (2001). International market selection strategies of manufacturing and services firms. Entrepreneurship and Regional Development. Vol.13. pp. 17- 46 
62. Xu Shichun, Cavusgil S. Tamer and White J. Chris (2006). The Impact of Strategic Fit Among Strategy, Structure, and Processes on Multinational Corporation Performance: A Multimethod Assessment .Journal of International Marketing. Vol. 14. No. 2. pp 1-31

63. Zou Shaoming \& Stan Simona (1998). The determinants of export performance: a review of the empirical literature between 1987 and 1997. International Marketing Review. Vol. 15 No. 5. pp. 333-356

64. The web site of Trade Development Organization (www.tpo.ir) 